\title{
Roles of Capital Adequacy and Liquidity to Improve Banking Performance
}

\author{
Hery MARGONO ${ }^{1}$, Mursida Kusuma WARDANI ${ }^{2}$ Julia SAFITRI $^{3}$
}

Received: August 01, 2020 Revised: September 28, 2020 Accepted: October 05, 2020

\begin{abstract}
This study aims to empirically test the effect of liquidity and adequacy on bank performance through interest rate risk and credit risk. Capital adequacy and liquidity are variables that can affect the ups and downs of opinion, where the bank's performance in this study is the dependent variable. Good credit distribution can minimize the occurrence of defaults. This study uses banking companies in Indonesia that are listed on the Indonesian stock exchange, with a total number of 43 banking companies, this study however, uses only 30 companies ranging from years 2014 to 2019 , primarily due to the availability of the limited data. The data analysis techniques used in this study is PLS-SEM with the WarpPLS application. The research results show that capital adequacy and liquidity has a positive effect on bank performance, interest rate risk and credit risk can mediate capital adequacy on bank performance, interest rate risk can mediate liquidity on bank performance, and interest rate risk has a positive effect on bank performance. However, credit risk can't mediate liquidity on bank performance and credit risk does not have a positive effect on bank performance. This is in line with the commercial loan theory, shiftability theory and the doctrine of anticipated income, which explains how best to give credit, both in longer and the shorter term.
\end{abstract}

Keywords: Capital Adequacy, Liquidity, Bank Performance, Financial Intermediation

JEL Classification Code: G21, G24, G29

\section{Introduction}

Banks are intermediary institutions that collect funds from the public in the form of savings and channel them back to the public in the form of credit or other forms in order to accelerate the overall economic growth of a country. Banking in developing countries has become one of the institutions that plays a very important role in domestic economic activity because it is one of the sources of funding needed for domestic market activities when other sources of funding such as the capital market are still weak and limited so that they are unable to provide adequate funding sources for domestic market activities, economic activity and investment (Saci et al., 2009).

${ }^{1}$ First Author and Corresponding Author. Lecturer, Management Department, IPWI Economics Institute, Indonesia [Postal Address: Jl. Letda Natsir No 7 Cikeas Nagrak Gn Putri, Bogor, West Java, Indonesia] E-mail: herymargono88@gmail.com

'Lecturer, Management Department, IPWI Economics Institute, Indonesia. Email: idha_mkw@yahoo.com

${ }^{3}$ Lecturer, Management Department, IPWI Economics Institute, Indonesia. Email: phypit.js@gmail.com

(c) Copyright: The Author(s)

This is an Open Access article distributed under the terms of the Creative Commons Attribution Non-Commercial License (https://creativecommons.org/licenses/by-nc/4.0/) which permits unrestricted non-commercial use, distribution, and reproduction in any medium, provided the original work is properly cited.
A bank is a type of financial institution, which is a part of the financial system, so in carrying out its function as an economic actor, it is influenced by macro factors as well as internal factors of the bank or bank specific factors. Risk management is the essence of the implementation of prudential principles in managing the bank, in a changing environment banks are faced with a number of risks, for example: credit risk, liquidity risk, exchange rate risk, market risk and only those banks are able to manage risks that can survive successfully (Powers et al., 2007).

The purpose of the banks are guided by the Law No.1 of 1998 which is to support national development activities so as to create equality, national stability and economic growth that makes an impact on increasing people's welfare. As the purpose of the bank contains large values so it is often a burden for banks to carry out their duties and functions according to these objectives. So, banks are not solely aiming for profit, but far beyond that. Risk management increases volatility (risk) in exchange rates, interest rates and commodity prices. The existence of this increased risk has triggered the need for new financial instruments and analytical tools to manage risk. Risk management is the design of procedures and implementation of procedures to control risk. Risk management emerged as a response to the increasing volatility of global financial markets as a result of 
technological innovation. Risk management aims to manage these risks so that we can get the most optimal results. In an organizational context, the organization will also experience many risks. If the organization is not able to manage risk properly, then the organization can suffer significant losses. Therefore, the risk faced by the organization must be managed, so that the organizations can survive, or optimize their risks. Companies often deliberately take certain risks, because they see the potential return behind these risks. Risk management is basically carried out through the following processes: Risk identification, risk evaluation and measurement, and risk management.

The next discussion is about credit risk, which is one of the many risks faced by the banks. Credit risk is a risk that promises cash flow from loan income and other securities owned by financial institutions that may not be fully repaid. Credit risk dominates the composition of the capital adequacy ratio, where $70 \%$ of capital is allocated for credit risk and $30 \%$ for market risk and operational risk. Thus, credit risk is the main cause of bank failure and this risk is most visible to bank managers (Garr, 2013). There is limited empirical research that examines the factors that affect credit risk. Bank risk is closely related to economic conditions and business turnover. When economic conditions experience a downturn or sluggishness, bad loans will also increase in number, at a time when the economy is booming (booming economics) will increase the volume of cash held by businesses or households, this will increase people's purchasing power so in turn it will increase the loan repayment ability of the people. This will lead to a reduction in bank credit risk.

\section{Literature Review}

\subsection{Grand Theory}

There are three theories used in this paper, namely risk management theory, financial intermediation theory, and liquidity preference theory. Credit is the provision of money or an equivalent claim, based on a loan agreement or agreement between a bank and another party which requires the borrowing party to pay off its debt after a certain period of time with interest. Risk management in bank operations includes risk identification, measurement and assessment, and the objective is to minimize the negative effects of risk on financial results and the bank capital. Banks are required to establish a special organizational unit for risk management purposes. As an intermediary financial institution that receives public funds, and subsequently distributes them back in the form of credit, banks must apply the principle of prudence in carrying out their operational activities so that the bank remains an institution that is trusted by the public (prudential banking activity). Credit risk is the risk where a customer / debtor or counterpart is unable to fulfill its financial obligations according to the contract / agreement that has been entered into. This definition can be expanded, namely that credit risk is a risk that arises due to decreasing credit quality. Boffey and Robson (1995) The main reason why proper management of credit risk is very important is because banks have a limited capacity to absorb loan losses. In a broad sense, the capacity of a bank to absorb loan losses comes, in the first example, from the income generated by other profitable loans and, in the second example, with the bank's capital. The income that a bank generates from a profitable loan is usually modest.

Financial Intermediation Theory was first put forward by Schumpeter in 1939, which states that financial intermediation is based on minimizing the production costs of information to solve intensive problems. Financial intermediation is the key to understanding why there is an advantage in supervision of an intermediary that depositors do not (Diamond, Douglas, 1984). Financial intermediation allows the best contracts as well as a large allocation as a positive role for the financial intermediation process. In general, loans and deposits with no high leverage result in a low probability of default (default). However, with the model of supervision and diversification, the possibility of default is still low. A number of other theories include Allen and Santomero (1997), Bikker et al. (2003), further stated that why banks and financial intermediaries in general can exist because they can mitigate the liquidity risk that occurs on the flow of funds from surplus parties (depositors) by becoming agents of parties who need funds (borrowers). The basis of the intermediation theory of financial intermediary institutions is to see banks as a solution to these problems, because banks have a comparative advantage regarding all information regarding the crediting values of debtors (Pyle, 1971), (Scholes et al., 1976) banks are better able to monitor debtors than individual creditors (Leland and Pyle, 1977), banks can provide greater liquidity than funds collected from the household and business sectors and can issue demand deposits that can be exchanged for funds (Fama, 1980).

Liquidity Preference Theory, which was originally developed by (J.M. Keynes, 1946) analyzes the equilibrium interest rate through the interaction of the money supply with the public's aggregate demand for holding money. Keynes assumed that most individuals hold wealth in only two forms: money and bonds. Liquidity preference theory structure is based on the supply and demand of money supply and the view that all financial decisions emphasize the monetary side of liquidity. Therefore, the loan fund model is developed based on the flow of funds in the financial system and views that financial decisions are made on a broader basis of liquidity. Historically, interest rates are almost as old as human civilization, in other words, interest rates have been around for a long time. This is in accordance with the opinion expressed by (Modigliani, 1944) which states that people who have borrowed goods from others are sometimes 
Hery MARGONO, Mursida Kusuma WARDANI, Julia SAFITRI /

asked for compensation for services rendered. This reward is called rent, which is the price of borrowing someone else's property. Tobin (1958) stated that interest is the amount of funds that is valued in money and received by the lender (creditor), while the interest rate is the ratio of the interest to the amount of the loan. So the interest rate is the price of borrowing money to use its purchasing power. The interest rate is one of the variables in the economy that is constantly being watched carefully because of its wide-ranging impact. Interest directly affects people's daily lives and has an important impact on the health of the economy from the perspective of consumption, credit, bonds and savings.

\subsection{Hypothesis Development}

\subsubsection{The Effect of Capital Adequacy on Bank Performance}

The capital adequacy standard for banks operating internationally is a major concern for regulatory banks around the world. Because of this, the Bank for International Settlements (BIS) established a framework for measuring capital adequacy for banks in the group of ten (G10) banking industry countries in the world. Capital adequacy standards affect bank performance (Prawitasari, et al., 2020; Ha, 2019; Ezike and Oke, 2013). Capital Adequacy Ratio (CAR) as an indicator of a bank's ability to cover a decline in assets as a result of losses suffered by a bank, the size of the CAR is determined by the bank's ability to generate profits and the composition of funds allocated to assets according to the level of risk. Some studies show that CAR has a partial positive effect on ROA (Chavarín, 2015), (Albulescu, 2015), (Malik et al., 2015), (Mayes and Stremmel, 2012), (Rahman et al., 2015), (Islam and Nishiyama, 2016), (Boadi et al., 2016), while (Owoputi et al., 2014), (Putranto et al., 2014). Based on these descriptions relating to capital adequacy and bank performance, the hypotheses proposed in this study are:

\section{$\boldsymbol{H}_{1}:$ Capital Adequacy has a Positive Effect on Bank} Performance.

\subsubsection{Effect of Liquidity on Bank Performance}

The relationship between bank liquidity as measured by the loan to deposit ratio (LDR) and profitability return on assets (ROA) has been studied in European banks with significant positive results (Bourke, 1989). These findings indicate that the greater the amount of credit extended, the greater the loan interest income received by the bank so that the return on assets increases. The results of this study also show that the greater the source of idle funds, the smaller the profitability.
The ability of a bank to provide sufficient funds to meet all obligations and commitments that have been issued to its customers at any time is called liquidity. Assessment of bank soundness using the Camel method contains, among others, the LDR ratio for liquidity measurement (Bank Indonesia, 2004). A bank with a low LDR, means that the amount of credit extended is relatively low, means that the opportunity to obtain interest income from loans is also low. A bank with a high LDR means that the opportunity to earn income from credit interest is relatively high (Camba, 2020). Money in the form of securities (Eichengreen and Gibson, 2001). The results of this study concluded that the greater the lending by the bank, the higher the profitability. Empirical research states that LDR has a positive effect on ROA (Lartey et al., 2013), (Jasevičienè, 2013), (Paleni, 2017), (Zainelden, 2018). Based on these descriptions relating to bank liquidity and performance, the hypotheses proposed in this study are:

\section{$\boldsymbol{H}_{2}$ : Liquidity has a positive effect on Bank Performance.}

\subsubsection{Interest Rate Risk as a Mediator of Capital Adequacy on Bank Performance}

Capital adequacy is a policy or regulation of a company or a bank in handling its capital. Capital is a fund that is invested by the owner in the context of establishing a business entity which is intended to finance bank business activities in addition to meeting the regulations set by the monetary authority (Bhattacharya, 2013). Adequate capital can increase public confidence, because it indicates that the bank can accommodate the possible risk of losses that will be experienced by the bank due to its operations. That way, capital adequacy will have an impact on increasing profits or profitability obtained by banks through loan interest rates. CAR is an indicator that is often used to measure the level of bank capital adequacy. CAR can be obtained by calculating the ratio or comparison between own capital and RWA. (Mayes and Stremmel, 2012), (Owoputi et al., 2014), (Jha and Hui, 2012). Based on this description, the hypotheses proposed in this study are:

$\boldsymbol{H}_{3}:$ Interest rate risk can mediate capital adequacy on bank performance

\subsubsection{Credit Risk as a Mediator of Capital Adequacy on Bank Performance}

Signaling theory or signal theory developed by Ross (1977) states that the company executives who have better information about their company will be encouraged to convey this information to potential investors so that the company's stock price increases. The positive thing with the signaling theory is that companies that provide good information will 
differentiate them from companies that don't have "good news" for informing the market about their situation. This is a signal about good future performance given by companies whose past financial performance has not been good. Such companies will be trusted by the market. Based on this description, the hypotheses proposed in this study are:

$\boldsymbol{H}_{4}:$ Credit risk can mediate capital adequacy on bank performance

\subsubsection{Interest Rate Risk as a Liquidity Mediator on Bank Performance}

Market risk is defined as the risk that arises due to the movement of market variables from the bank's portfolio which can harm the bank (Adverse Movement) (Goodfriend, 1991). The first effect, IRR has a positive or unidirectional effect on interest rate risk and negative or opposite direction to the level of the bank's ability to manage the income received with the costs incurred which is influenced by the interest rate. The second effect, namely the negative effect occurs when the IRR increases when the interest rate trend decreases. This will result in a smaller decrease in interest income than a decrease in interest costs, so that profit and ROA will also decrease. (Ross, 1998), (Zagonov, 2011), (Oberoi, 2017), (Papadamou and Siriopoulos, 2014). Based on this description, the hypotheses proposed in this study are:

\section{$\boldsymbol{H}_{5}:$ Interest rate risk can mediate liquidity on bank performance}

\subsubsection{The effect of credit risk as a liquidity mediator on bank performance}

If the IRR increases, it indicates an increase in Interest Rate Sensitive Assets (IRSA) with a greater percentage than the percentage increase in Interest Rate Sensitive Liabilities (IRSL). This situation will increase the risk of interest rates if interest rates decline, which means there is a negative relationship, but this situation will reduce the risk of interest rates if interest rates increase, which means there is a positive relationship. If interest rates increase, there will be an increase in interest income with a greater percentage than the percentage increase in interest costs, so that interest income and ROA will increase (Gallitschke et al., 2017), (Drehmann et al., 2010), (Fernandez , 2004; Esposito et al., 2015). Based on this description, the hypotheses proposed in this study are:

\section{$\boldsymbol{H}_{6}:$ Credit risk can mediate liquidity on bank performance}

Based on hypotheses 1, 2, 3, 4, 5 and then hypotheses 7 and 8 can be submitted, namely:

$\boldsymbol{H}_{7}$ : Interest rate risk has a positive effect on bank performance
$\boldsymbol{H}_{\boldsymbol{g}}$ : Credit risk has a positive effect on bank performance

\section{Research Method}

The object of this research is banking companies listed on the stock exchange from 2014 to 2019. The population in this study are banking companies listed on the Indonesia Stock Exchange. In this study, the data analysis technique used Partial Least Squares (PLS) - Structural Equation Modeling (SEM) with the WarpPLS 6.0 application. Based on that this research is predictive and exploratory. The use of PLS-SEM considers several advantages, including; SEM PLS can work efficiently with small sample sizes and complex models, the assumption of data distribution in SEM-PLS is relatively more loose than other methods such as CB (Covariance-based) -SEM (Sholihin and Ratmono, 2013). To test hypotheses 1 to hypothesis 8 , the following model equation can be made:

$$
\begin{gathered}
\begin{array}{c}
\mathrm{ROA}=\alpha 1+\beta 1 \mathrm{CARt}+\beta 2 \mathrm{LDR}+\beta 3 \mathrm{IRR} \\
\\
+\beta 4 \mathrm{RAROC}+\in 1
\end{array} \\
\mathrm{IRR}=\alpha 2+\beta 1 \mathrm{CAR}+\beta 2 \mathrm{LDR}+\in 2 \\
\mathrm{RAROC}=\alpha 1+\beta 1 \mathrm{CARt}+\beta 2 \mathrm{LDR}+\in 3
\end{gathered}
$$

\section{Results}

The results of testing the first hypothesis show that liquidity has a positive effect on bank performance, this is indicated by a coefficient value of 0.148 and a p-value of 0.021 , so the first hypothesis is accepted. For testing the second hypothesis, namely capital adequacy has a positive effect on bank performance with a coefficient value of 0.265 and $\mathrm{p}$-value $<0.001$ consistent with the hypothesis so this hypothesis is accepted. Furthermore, the third hypothesis, namely interest rate risk can mediate the effect of capital adequacy on bank performance, with a coefficient value of 0.152 and a p-value of 0.019 , this third hypothesis is accepted. The fourth hypothesis is that credit risk can mediate the effect of capital adequacy on bank performance, where the coefficient value is 0.705 and the p-value is $<0.001$, this hypothesis is accepted. And then the fifth hypothesis of interest rate risk can mediate the influence of liquidity on bank performance with a coefficient value of 0.139 and a p-value of 0.028 , so this hypothesis is accepted. The sixth hypothesis is that credit risk can mediate the effect of liquidity on bank performance, where the coefficient value is -0.036 and the $p$-value is 0.134 , so this hypothesis is rejected. Furthermore, the seventh hypothesis, namely interest rate risk has a positive effect on bank performance, with a coefficient value of 0.123 and a p-value of 0.046 , this hypothesis is accepted. The eighth hypothesis that credit risk has a positive effect on bank performance, with a coefficient value of -0.012 and a p-value of 0.434 , this hypothesis is rejected. (See Table 1) 
Table 1: Path coefficient and P-Value

\begin{tabular}{|l|c|c|}
\hline Descriptive Path & Path Coefficient & P-Value \\
\hline LDR $\rightarrow$ ROA & 0.148 & 0.021 \\
\hline $\mathrm{CAR} \rightarrow \mathrm{ROA}$ & 0.265 & $<0.001$ \\
\hline $\mathrm{CAR} \rightarrow \mathrm{IRR}$ & 0.151 & 0.019 \\
\hline $\mathrm{CAR} \rightarrow \mathrm{RAROC}$ & 0.705 & $<0.001$ \\
\hline $\mathrm{LDR} \rightarrow \mathrm{IRR}$ & 0.139 & 0.028 \\
\hline $\mathrm{LDR} \rightarrow \mathrm{RAROC}$ & -0.036 & 0.134 \\
\hline $\mathrm{IRR} \rightarrow \mathrm{ROA}$ & -0.123 & 0.046 \\
\hline $\mathrm{RAROC} \rightarrow \mathrm{ROA}$ & -0.012 & 0.434 \\
\hline
\end{tabular}

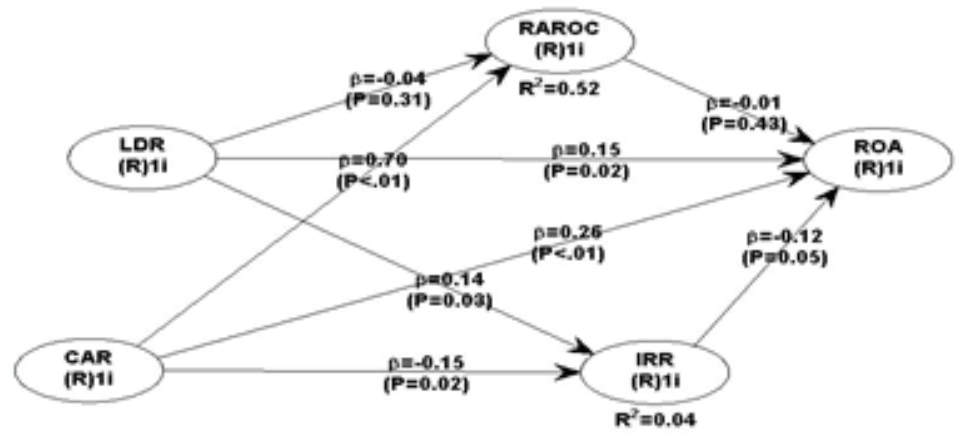

Source: WarpPLS 6.0 data processing

Figure 1: Full Model Research

According to Baron and Kenny (1986), in an analysis model that utilizes mediating variables, it can be seen whether there is full mediation or partial mediation. Full mediation is a time when the independent variable does not have a significant effect on the dependent variable when there is no mediator. Meanwhile, partial mediation is when the independent variable can directly influence the dependent variable without involving the mediator variable. In addition, the mediating variable occurs because the independent variable can predict the dependent variable directly, but its value is smaller than the predicted value of the mediator variable. In this case, if the coefficient of the prediction variable is greater than the coefficient of the mediating variable on the dependent variable, it should not be called a mediator. Testing the indirect effect and the total effect to determine the coefficient value of the indirect relationship. In this study, following the procedures as formulation and the stages of mediation testing proposed by (Baron and Kenny, 1986). (See Table 2)

Based on the results of testing the mediation effect in the table above the indirect effect coefficient for testing the mediation hypothesis of $\mathrm{LDR} \rightarrow \mathrm{IRR} \rightarrow \mathrm{RAROC} \rightarrow \mathrm{ROA}$ is 0.017 with a $p$-value of $0.041(\mathrm{p}<10 \%)$. These results explain that the IRR and RAROC values are able to insignificantly mediate the effect of liquidity on bank performance. In testing the direct path relationship LDR $\rightarrow$ ROA is significant at 0.036 . Meanwhile, the direct connection path is $\mathrm{CAR} \rightarrow \mathrm{IRR}$ $\rightarrow$ RAROC $<0.001$. Likewise, the direct connection path IRR $\rightarrow$ RAROC $\rightarrow$ ROA is 0.028 . It can be concluded that there is partial mediation in the liquidity relationship (LDR) to bank performance (ROA) through INRISK as a partial mediation variable.

According to Latan and Ghozali (2016), to find out how much the variance of the mediating variable is able to absorb the previously significant direct effect of the model without mediation, the VAF calculation measure is used. This VAF calculation method is seen as a more suitable measurement model, because it does not require any assumptions about the distribution of the variables so that it can be applied to small sample sizes. The VAF (variance accounted for) values ranged between 0 and 1 where the higher the VAF value, the more perfect the mediation effect was. The calculation of VAF can be used to test the effect of mediation by referring to the VAF criteria $>80 \%$, it means that there is full mediation, if $20 \% \leq \mathrm{VAF} \leq 80 \%$ means partial mediation and VAF $<20 \%$ means no. there is a mediating effect in the model (no mediation). The results of mediation testing with the VAF method can be seen Table 3 below: 
Table 2: Indirect Effect dan Total Effect

\begin{tabular}{|l|c|c|}
\hline Indirect Effect & Path Coefficient & P-Value \\
\hline $\mathrm{LDR} \rightarrow \mathrm{RR} \rightarrow \mathrm{RAROC} \rightarrow \mathrm{ROA}$ & 0.017 & 0.041 \\
\hline $\mathrm{CAR} \rightarrow \mathrm{RR} \rightarrow \mathrm{RAROC} \rightarrow \mathrm{ROA}$ & 0.010 & 0.447 \\
\hline Total Effect & Path Coefficient & P-Value \\
\hline $\mathrm{LDR} \rightarrow \mathrm{RR} \rightarrow \mathrm{RAROC} \rightarrow \mathrm{ROA}$ & 0.131 & 0.036 \\
\hline $\mathrm{CAR} \rightarrow \mathrm{RR} \rightarrow \mathrm{RAROC} \rightarrow \mathrm{ROA}$ & 0.274 & $<0.001$ \\
\hline
\end{tabular}

Table 3: VAF Calculation

\begin{tabular}{|l|c|c|c|}
\hline & Indirect Effect & Total Effect & VAF (Indirect/total effect) \\
\hline $\mathrm{LDR} \rightarrow \mathrm{IRR} \rightarrow \mathrm{RAROC} \rightarrow \mathrm{ROA}$ & 0.017 & 0.139 & $0.122=12.2 \%$ \\
\hline $\mathrm{CAR} \rightarrow \mathrm{IRR} \rightarrow \mathrm{RAROC} \rightarrow \mathrm{ROA}$ & 0.010 & 0.274 & $0.274=27.4 \%$ \\
\hline
\end{tabular}

The results of data processing shown in the table above show that the IRR and RAROC variables are the mediating variables for the relationship between liquidity (LDR) and bank performance (ROA), the VAF value is 0.122 or $12.2 \%$ which means that IRR and RAROC do not mediate because $12.2 \%<20 \%$. Furthermore, capital adequacy (CAR) on bank performance (ROA) through IRR and RAROC as mediation has a value of 0.274 or $27.4 \%$, which means that IRR and RAROC can mediate what is called partial mediation.

\section{Conclusion}

The results of this study found that liquidity has a direct effect on financial performance. Where hypotheses 1, 2, 3, 4, 5,8 are accepted, but hypothesis 6,8 is rejected. So it can be concluded that the higher the liquidity, the higher the bank profit. This is in line with the objectives of liquidity and in line with several theories about liquidity which are proxied by the LDR (loan to deposit ratio), which is where the important purpose of calculating the LDR is to find out and assess to what extent a bank is in a healthy condition in carrying out its operations or business activities. Furthermore, capital adequacy proxied by CAR (capital adequacy ratio) has a positive effect on bank performance. This is in line with the definition of CAR, which is a capital ratio that indicates a bank's ability to provide funds for business development needs and accommodate the risk of loss of funds caused by bank operations. CAR shows the extent to which the decline in bank assets can still be covered by available bank equity, the higher the CAR the better the condition of a bank.

\section{References}

Albulescu, C. T. (2015). Banks' profitability and financial soundness indicators: A macro-level investigation in emerging countries. Procedia Economics And Finance, 23, 203-209.
Baron, R. M., \& D. A. Kenny. (1986). The moderator-mediator variable distinction in social psychological research: Conceptual, strategic, and statistical considerations. Journal of Personality and Social Psychology, 51(6), 1173.

Boadi, E. K., Li Y., \& Lartey, V. C. (2016). Role of bank specific, macroeconomic and risk determinants of banks profitability: Empirical evidence from Ghana's rural banking industry. International Journal of Economics and Financial Issues, 6(2), 813-823.

Boffey, R. \& G. N. Robson. (1995). Bank credit risk management. Managerial Finance, 21(1), 66-78.

Camba, A. C., \& Camba, A. L. (2020). The Dynamic Relationship of Domestic Credit and Stock Market Liquidity on the Economic Growth of the Philippines. Journal of Asian Finance, Economics and Business, 7(1), 37-46. https://doi.org/10.13106/ jafeb.2020.vol7.no1.37

Chavarín, R. (2015). Determinants of Commercial Bank Profitability in Mexic). EconoQuantum, 12(1), 51-77.

Diamond, D. W., \& Dybvig, P. H. (1983). Bank runs, deposit insurance, and liquidity. Journal of Political Economy, 91(3), 401-419.

Drehmann, M., Sorensen, S., \& Stringa, M. (2010). The integrated impact of credit and interest rate risk on banks: A dynamic framework and stress testing application. Journal of Banking \& Finance, 34(4), 713-729.

Eichengreen, B., \& Gibson. H. (2001). Greek banking at the dawn of the new millennium. Internasional Macroeconomic, 3(2791), 90-98

Esposito, L., Nobili, A., \& Ropele, T. (2015). The management of interest rate risk during the crisis: Evidence from Italian banks. Journal of Banking \& Finance, 59(2), 486-504.

Ezike, J. E., \& Oke, M. O. (2013). Capital Adequcy Stabndars, Basle accord and Bank Peformance : Nigerian Experience ( studi case selected banks in Nigeria). Asian Economic and Financial Review, 3(2), 146-159 
Fama, E. F. (1980). Banking in the Theory of Finance. Journal of Monetary Economics, 6(1), 39-57.

Fernandez, V. (2004). Interest rate risk in an emerging economy. The Quarterly Review of Economics and Finance, 44(5), 678-709.

Filomena, J., B. P., Simona, V. (2013). Commercial Banks Performance 2008-2012. Business, Managemnet and Education, 11(2), 189-208

Filomena, J. D. J. (2014). The New capital adequacy framework (Basel III) options And issue In Commercial Banks Of Lithuania. Journal Ekonomika, 11(2), 189-208

Franklin, A., \& Santomero, A. (1997). The theory of financial intermediation. Journal of Banking \& Finance, 21(11-12), 1461-1485.

Gallitschke, J., Seifried, S., \& Seifried, F. T. (2017). Interbank interest rates: Funding liquidity risk and XIBOR basis spreads. Journal of Banking \& Finance, 78(2), 142-152.

Garr, D. K. (2013). Determinants of credit risk in the banking industry of Ghana. Developing Country Studies, 3(11), 2225-0565.

Goodfriend, M. (1991). Interest rates and the conduct of monetary policy. Carnegie-Rochester Conference Series on Public Policy, 34(1), 7-30.

Ha, D. V. (2019). The Interactive Relationship between Credit Growth and Operational Self-Sustainability of People's Credit Funds in Mekong Delta Region of Vietnam. Journal of Asian Finance, Economics and Business, 6(3), 55-65. https://doi. org/10.13106/jafeb.2019.vol6.no3.55

Herman, P., \& Subuh. H., \& Dadang P., J. (2017). Determinants of Profitability: Evidence from Indonesian Firms. International Journal of Economic Perspective, 11(3), 1049-1057

Hrishikes, B. (2013). Capital Regulation And rising Risk of Banking Industry: A financial Accounting Perspective. Academy of Banking Studies Journal, 12(1), 31-59

Islam, M. S., \& Nishiyama, S. I. (2016). The Determinants of Bank Profitability: Dynamic Panel Evidence from South Asian Countries. Journal of Applied Finance and Banking, 6(3), 77-97.

Jha, S., \& Hui, X. (2012). A comparison of financial performance of commercial banks: A case study of Nepal. African Journal of Business Management, 6(25), 7601-7612.

Lartey1, V. C., Antwi1, S., \& Boadi, E. K. (2013). The Relationship between Liquidity and Profitability of Listed Banks in Ghana. International Journal of Business and Social Science, 4(3), 48-56

Leland, H. E., \& Pyle. E. K. (1977). Informational asymmetries, financial structure, and financial intermediation. The Journal of Finance, 32(2), 371-387.

Malik, R., Baig, S. A., Abbass, Z., \& Zia-ur-Rehman, M. (2015). Bank Peculiar, Macroeconomic Causes and Profitability of Banks: An Evidence from Pakistan. International Journal of Information, Business and Management, 7(4), 14-29.

Mayes, D. G., \& Stremmel, H. (2012). The effectiveness of capital adequacy measures in predicting bank distress. SUERF Studies, $3(1), 1-46$
Modigliani, F. (1944). Liquidity preference and the theory of interest and money. Journal of the Econometric Society, 12(1), 45-88.

Oberoi, J. (2017). Interest rate risk management and the mix of fixed and floating rate debt. Journal of Banking \& Finance, 17(2) 1-53.

Owoputi, J. A., Kayode, O. F., \& Adeyefa, F. A. (2014). Bank specific, industry specific and macroeconomic determinants of bank profitability in Nigeria. European Scientific Journal, 10 (25).

Paleni, H. H., Jatmiko, S., \& Prasetyo, D. (2017). Determinants of Profitability: Evidence from Indonesian Firms. International Journal of Economic Perspectives, 11(3), 1049-1057.

Papadamou, S., \& Siriopoulos, C. (2014). Interest rate risk and the creation of the Monetary Policy Committee: Evidence from banks' and life insurance companies' stocks in the UK. Journal of Economics and Business, 71, 45-67.

Powers, M. R., Hassan H. A., \& Al-Mazrooei, F. M. (2007). Banks' risk management: a comparison study of UAE national and foreign banks. The Journal of Risk Finance, 8(4), 394-409.

Prawitasari, D., Kadarningsih, A., Machmuddah, Z., Ud Din, M. (2020). Internal Company Factors as Determining Variables for Improving Bank Lending. Journal of Asian Finance, Economics and Business, 7(8), 205-212. https://doi.org/10.13106/ jafeb.2020.vol7.no8.205

Pyle, D. H. (1971). On the theory of financial intermediation. The Journal of Finance, 26(3), 737-747.

Rahman, M. M., Hamid, M. K. \& Khan, M. A. M. (2015). Determinants of bank profitability: Empirical evidence from Bangladesh. International Journal of Business And Management, 10(8), 135-150.

Ross, L. (1977). The intuitive psychologist and his shortcomings: Distortions in the attribution process. Advances in Experimental Social Psychology, 1010(2) 173-220.

Saci, K., Giorgioni, G. \& Holden, K. (2009). Does financial development affect growth?. Applied Economics, 41(13), 17011707.

Scholes, M., G., Benston, J., \& Smith, C. W. (1976). A transactions cost approach to the theory of financial intermediation. The Journal of Finance, 31(2), 215-231.

Paunović, S., Popovic, B., Kovačević, D. (2016). Profitability Of Banks In Bosnia And Herzegovina: Panel Analysis. Proceedings of the Faculty of Economics in East Sarajevo, 13, 11-16

Tobin, J. (1958). Liquidity preference as behavior towards risk. The Review of Economic Studies, 25(2), 65-86.

Zagonov, M. (2011). Financial Intermediation and Interest Rate Risk. City Research Online, 1(1), 1-228

Zainelden, M. (2018). Liquidity and Profitability. Journal of International Trade, Logistics and Law, 4(1), 44-53. 